LWSA

PAPER - OPEN ACCESS

\title{
Peran Laporan Keuangan Pemerintah Daerah Berbasis Akrual Sebagai Wujud Akuntabilitas Publik
}

\author{
Author \\ : Idhar Yahya \\ DOI \\ : 10.32734/lwsa.v1i1.142 \\ Electronic ISSN \\ : 2654-7058 \\ Print ISSN \\ : 2654-7066
}

Volume 1 Issue 1 - 2018 TALENTA Conference Series: Local Wisdom, Social and Arts

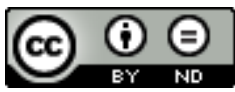

This work is licensed under a Creative Commons Attribution-NoDerivatives 4.0 International License.

Published under licence by TALENTA Publisher, Universitas Sumatera Utara
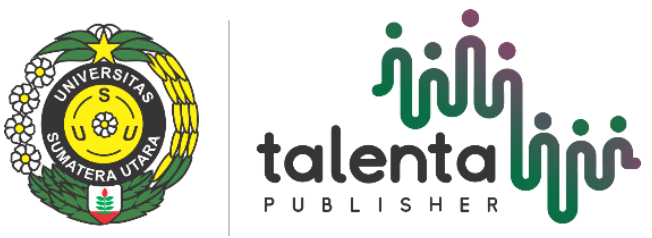


\title{
Peran Laporan Keuangan Pemerintah Daerah Berbasis Akrual Sebagai Wujud Akuntabilitas Publik
}

\author{
Idhar Yahya ${ }^{\mathrm{a}}$, M. Zainul B. Torong ${ }^{\mathrm{a}}$, Muslich Lufth ${ }^{\mathrm{b}}$ \\ ${ }^{a}$ Departemen Akuntansi, Fakultas Ekonomi dan Bisnis, Universitas Sumatera Utara, Medan-20155, Indonesia \\ ${ }^{b}$ Departemen Manajemen, Fakultas Ekonomi dan Bisnis, Universitas Sumatera Utara, Medan-20155, Indonesia
}

idharyahya@gmail.com

\begin{abstract}
Abstrak
Penerapan Laporan Keuangan Pemerintah Daerah (LKPD) Akrual di pemerintah daerah menjadi kajian penting. Keberhasilan kebijakan pemerintah dalam pertanggungjawaban anggaran direpresentasikan oleh laporan keuangan. LKPD berisikan berbagai informasi penting yang mencirikan realisasi keberhasilan Pemda sesuai dengan undang-undang sebagai wujud akuntabilitas pengelolaan keuangan negara dalam menjalankan amanah rakyat. Makalah ini menjelaskan tentang peran LKPD sebagai wujud informasi yang relevan mengenai posisi keuangan dan seluruh transaksi yang dilakukan oleh entitas pelaporan dalam periode pelaporan.LKPD digunakan untuk mengetahui nilai sumber daya ekonomi yang dimanfaatkan untuk melaksanakan kegiatan operasional, menilai kondisi keuangan, mengevaluasi efektivitas dan efisiensi dan membantu menentukan ketaatan terhadap peraturan perundan-undangan. Tujuan penelitian ini untuk dapat menentukan keberhasilan penerapan LKPD Akrual secara berkelanjutan. Studi dilakukan di Kabupaten Humbang Hasudutan dan Labuhan Batu Selatan (Labusel) yang merupakan bagian dari Pemerintah Provinsi Sumatera Utara. Pengumpulan data dilakukan dengan mengedarkan kuesioner yang disebarkan kepada Satuan Kerja Perangkat Daerah (SKPD) pada kedua Kabupaten tersebut dengan masing-masing 57 kuesioner dan 21 kuesioner. Penilaian dilakukan dengan melakukan observasi, tanya jawab serta mengevaluasi LKPD audited kedua Kabupaten dimaksud serta menganalisis skor jawaban dari responden. Responden adalah PPK-SKPD, bendahara pengeluaran dan pengurus barang. Agregasi nilai jawaban menjadi faktor penilain keberhasilan dari ke dua Kabupaten tersebut. Ada 4 jawaban yang berkaitan dengan karakteristik kualitatif laporan keuangan, 1 kepatuhan terhadap UU, 1 pencapain hasil, 1 kecukupan bukti serta 1 jawaban tentang pertanggung jawaban. Hasil penilaian menunjukkan bahwa karakteristik kualitas laporan keuangan sangat dominan sebagai faktor/syarat keberhasilan akan kualitas LKPD akrual sesuai dengan harapan pemerintah. pada kedua Kabupaten tersebut, sedangkan 4 jawaban lainnya relatif sama.
\end{abstract}

Kata kunci : LKPD; akrual; karakteristik kualitatif; laporan keuangan

\section{Pendahuluan}

Pengelolaan keuangan negara yang akuntabel dan transparan menjadi menjadi isu yang sangat penting di Pemerintahan Republik Indonesia hingga saat ini. Sebagai wujudnya pemerintah mengeluarkan seperangkat Undang-undang dan peraturan, antara lain UU Nomor 17 tahun 2003, UU Nomor 1 tahun2004 serta berbagai peraturan tambahan lainnya. Tambahan 2 Peraturan pemerintah (PP) yang diterbitkan terakhir masing-masing PP Nomor 24 tahun 2005 tentang Standar Akuntansi

Pemerintah(SAP). PP ini mengatur mengenai pengakuan pendapatan dan belanja menggunakan basis kas, sedangkan untuk aset, kewajiban, dan ekuitas menggunakan basis akrual. Sedangkan PP Nomor 71 tahun 2010 
merupakan pengganti PP Nomor 24 Tahun 2005. PP Nomor 71 Tahun 2010 tersebut memberlakukan SAP berbasis akrual baik untuk pendapatan, belanja, aset, kewajiban, dan ekuitas paling lambat Tahun 2015.

Penerapan akuntansi berbasis akrual dimaksudkan untuk memperbaiki kualitas penyajian laporan keuangan pemerintah dan menyajikan data yang akurat dalam mengukur kinerja pemerintah. Dalam akuntansi berbasis akrual dapat menunjukkan bagaimana pemerintah membiayai aktivitas dan memenuhi kebutuhan dananya, sehingga memungkinkan pengguna laporan keuangan untuk mengevaluasi kemampuan pemerintah saat ini untuk membiayai aktivitas dan memenuhi kewajibannya; serta lebih riil menunjukkan posisi keuangan pemerintah dan perubahan posisi keuangannya. Selain itu, dapat lebih memberikan kesempatan pada pemerintah untuk menunjukkan keberhasilan pengelolaan sumber daya yang dikelolanya; dan berguna untuk mengevaluasi kinerja pemerintah dalam hal efisiensi dan efektifivitas penggunaan sumber daya.

Adapun tujuan dari makalah ini adalah untuk mengetahui dan memahami serta menganalisis kemampuan pemahaman atas kualitas laporan keuangan (LK) aparat pemerintah di lingkungan pemerintah daerah, sesuai dengan kerangka konseptual dalam PP Nomor 71 Tahun 2010. LK yang berkualitas haruslah memenuhi karakteristik kualitatif, yaitu ukuran-ukuran normatif yang perlu diwujudkan dalam akuntansi sehingga dapat memenuhi tujuannya. Keempat karakteristik LK pemerintah adalah relevan, keandalan, dapat diperbndingkan dan dapat dipahami. Penjelasnnya :

1. Relevan diamksudkan adalahlaporan keuangan harus memuat informasi yang dapat mempengaruhi keputusan pengguna untuk mengevalusi peristiwa masa lalu, masa kini dan prediksi masa depan. Relevan disini juga dipertegas, bahwa informasi haruslah mampu memberikan manfaat umpan balik (feedback value), manfaat masa depan (predictive value) dan ketepatan waktu serta lengkap.

2. Keandalan, maksudnya laporan keuangan harus bebas dari pengertian yang menyesatkan dan kesalahan material, penyajianya sesuai fakta secara jujur, serta dapat diverifikasi kebenarannya dan keberadaanya.

3. Dapat diperbandingkan, laporan keuangan disajikan secara perbandingan dengan tahun lalu, sehingga lebih bermanfaat. Perbandingan juga dilakukan secara internal (dilakukan bila suatu entitas menerapkan kebijakan akuntansi yang sama dari tahun ke tahun) sementara secara eksternal (dilakukan bila entitas yang diperbandingkan menerapkan kebijakan akuntansi yang sama). Lebih lanjut pengungkapan harus dilakukan apabila kebijakan akuntansi yang lebih baik daripada kebijakan akuntansi yang sekarang diterapkan.

4. Dapat dipahami, informasi yang disajikan dalam laporan keuangan dapat dipahami oleh pengguna dan dinyatakan dalam bentuk serta istilah yang disesuaikan dengan batas pemahaman para pengguna. Untuk itu, pengguna diasumsikan memiliki pengetahuan yang memadai atas kegiatan dan lingkungan operasi entitas pelaporan, serta adanya kemauan pengguna untuk mempelajari informasi tersebut.

\section{Metode penelitian}

Pengumpulan data dilakukan dilingkungan SKPD Labuhan Batu Selatandan. Kabupaten Humbang Hasudutan. Data dikumpulkan dan dianalisis dari 51 orang responden dari Kabupaten Labusel sebanyak 21 orang responden. Hasil dari jawaban koesioner merupakan persepsi dari sikap dan pendapat masing- masing responden terhadap substansi pernyataan atas koesioner yang diedarkan. Disamping jawaban responden, analisis juga dilakukan berdasarkan observasi tidak langsung dan LKPD yang audited dari kedua kabupeten tersebut.

\section{Hasil dan pembahasan}

\subsection{Kabupaten Labuhan Batu Selatan}

Hasil analisis atas jawaban responden dilakukan pembahasan dan dianalisis sesuai dengan urutannya masingmasing kuesioner dimana untuk 4 item pertanyaan tentang kualitas laporan keuangan daerah, berkaitan dengan relevan, keandalan,dan dapat diperbandingkan serta dapat dipahami. Hal tersebut menunjukkan bahwa $71 \%$ sampai $85 \%$ responden memberikan jawaban baik sehingga dapat dikatakan LK pemerintah Kabupaten Labuhan Batu Selatan telah dapat terlaksana dengan baik dan sangat memuaskan. 
Pada 4 item pertanyaan berikutnya terlihat bahwa ketaatan atas peraturan yang berlaku, kecukupan bukti, pencapai target maupun hasil program yang ditetapkan serta pertanggungjawaban yang handal menunjukkan bahwa $71 \%$ responden memberikan jawaban baik. Hal tersebut berarti LK pemerintah Kabupaten Labuhan Batu Selatantelah memenuhi kecukupan bukti, pencapai target maupun hasil program yang ditetapkan serta pertanggungjawaban LK yang handal.

\subsection{Kabupaten Humbang Hasudutan}

Hasil analisis atas jawaban responden dilakukan pembahasan dan dianalisis sesuai dengan urutannya masingmasing kuesioner dimana untuk 4 item pertanyaan tentang kualitas laporan keuangan daerah, berkaitan dengan relevan, keandalan,dan dapat diperbandingkan serta dapat dipahami. Hal tersebut menunjukkan bahwa $42 \%$ sampai $49 \%$ responden memberikan jawaban baik, sehingga dapat dikatakan LK pemerintah Kabupaten Humbang Hasudutan telah dapat terlaksana dengan baik, meskipun belum dapat dikatakan memuaskan, sehingga perlu peningkatan dimasa yang akan datang.

Untuk 4 item pertanyaan berikutnya, ketaatan atas peraturan yang berlaku, kecukupan bukti, pencapai target maupun hasil program yang ditetapkan serta pertanggungjawaban yang handal menunjukkan bahwa $42 \%$ sampai 63 $\% \%$ responden memberikan jawaban baik. Hal tersebut berarti LK pemerintah Humbang Hasudutan juga telah memenuhi kecukupan bukti, pencapai target/ hasil program yang ditetapkan serta pertanggungjawaban LK yang handal.

\section{Kesimpulan}

Semakin menigkatnya tuntutan masyarakat atas pelaksanaan pengelolaan keuangan negara yang transparan dan akuntabel mendorong pemerintah untuk terus berupaya menyajikan laporan keuangan pemerintah yang berkualitas sesuai dengan persyaratan peraturan yang berlaku, sebagai wujud akuntabilitas publik atas pelaksanaan APBD. Kualitas laporan keuangan pemerintah akan terus meningkat sesuai dengan meningkatnya penggunaan sumberdaya setiap tahunnya.

\section{References}

[1] Republik Indonesia, Undang-Undang Nomor 17 Tahun 2003 tentang Keuangan Negara.

[2] Republik Indonesia, Undang-Undang Nomor 1 Tahun 2004 tentang Perbendaharaan Negara.

[3] Republik Indonesia, Peraturan Pemerintah Nomor 58 Tahun 2005 tentang Pengelolaan Keuangan Daerah.

[4] Republik Indonesia. Peraturan Pemerintah Nomor 24 Tahun 2005 tentang Standar Akuntansi Pemerintahan

[5] Republik Indonesia. Peraturan Pemerintah Nomor 71 Tahun 2010 tentang Standar Akuntansi Pemerintahan

[6] BPK - RI. (2013). Ikhtisar Hasil Pemeriksaan Semester II Tahun 2013, Jakarta. 